\title{
RECLAMATION OF PHOSPHOGYPSUM DEPOSITION SITE IN WISLINKA NEAR GDANSK WITH MUNICIPAL SEWAGE SLUDGE
}

\author{
Piotr Kowalik \\ Ewa Wojciechowska \\ Technical University of Gdansk, Poland
}

\begin{abstract}
Utilization of sewage sludge is becoming one of the biggest environmental problems. One of the possible solutions is application of sludge to soil amendment. Sludge is a good natural fertilizer due to high concentration of organic carbon and nutrient elements $(\mathrm{N}, \mathrm{P})$. On the contrary, sewage sludge also contains heavy metals and may be contaminated with enteric parasites. Thus application of sludge to land could result in contamination of surface and ground waters and including trace metals in the food chains due to contamination of plants grown on sludge amended soils. Hence land application of sludge ought to be carefully monitored and follow stringent regulations, which are often difficult to fulfil. However, if sludge is applied to reclamation of degraded post-industrial lands, waste deposition sites, landfills and formation of soil-like surface layer on soil-less grounds, the restrictions are not so stringent and easier to fulfil than in cases when crops are grown on sludge amended soils.

In the article reclamation of a phosphogypsum deposition site in Wislinka near Gdansk using sewage sludge from a municipal wastewater treatment plant (WWTP) is discussed. Phosphogypsum deposit in Wislinka for many years has been one of the biggest environmental problems of the region, causing permanent complainants from local communities. Reclamation of the deposition site started in 1999 and has been continued up till now. Covering of the slopes with a layer of sludge reduces dangerous wind erosion of dust and promotes plants succession.
\end{abstract}

\section{KEYWORDS}

sewage sludge, land application, phosphogypsum, land reclamation, heavy metals 


\section{INTRODUCTION}

Treatment of municipal and industrial wastewater, though inevitable to protect water resources, results in production of large amounts of waste: sewage sludge. One of the aspects of introducing modern and highly-effective methods of sewage treatment is an increase of generated sludge quantities.

The task of sewage sludge utilization meets a lot of difficulties due to its specific properties: high content of water and possible health hazards imposed by toxic heavy metals, organic compounds and pathogenic microorganisms that could be present in the sludge. Because of these features, sludge requires expensive multi-stage processing in the WWTP before it is taken away to the disposal site - it is estimated that costs of sludge processing amount to $50 \%$ or sometimes even more of the whole operation costs of WWTPs [1]. However sludge processing cannot eliminate the problems with its utilization, which include logistic, economic, environmental and social aspects. Thus sludge disposal and utilization becomes one of the biggest environmental problems.

There are three basic methods of sludge utilization: incineration, land application (soil fertilization and land reclamation) and landfilling. Although each of these methods has important disadvantages, the last one - landfilling - seems to have more drawbacks than two other methods. First of all, the costs of landfill siting, building, operation, monitoring and site reclamation tend to increase [2]. Then, deposition of wastes with organic matter content higher than 5\% will be banned in Germany in 2005 and probably other European countries will follow. Thus, incineration and land application will most likely become the leading sludge utilization methods in the near future. The agricultural utilization of sewage sludge is based upon the opinion that its chemical composition is similar to the composition of soil organic substance - humus [3]. In the UE approximately $33 \%$ of sewage sludge is utilized in agriculture and about $1 \%$ of sludge is applied for reclamation of soil-less lands. Some authors believe that a large part of plants biomass is transported to the cities as agricultural products and that this biomass ought to be returned to the agricultural sites "due to Natural Law") [3]. Unfortunately, excessive amounts of zinc and cadmium present in sludge are toxic for plants, humans and for animals. Thus, excessive concentration of these heavy metals seems to be the greatest obstacle in agricultural application of the sludge.

In the article an example of application of dewatered sewage sludge from municipal WWTP in Gdansk to reclamation of phosphogypsum waste tip in Wislinka near Gdansk is discussed.

\section{POLISH REGULATIONS CONCERNING LAND APPLICATION OF SEWAGE SLUDGE}

Since sewage sludge contains specific pollutants, such as heavy metals and because of health hazards created by both heavy metals and pathogens that could be present in it, land application of sludge is restricted and has to follow stringent regulations. The overall 
KALMAR ECO-TECH'03

Bioremediation and Leachate Treatment

KALMAR, SWEDEN, November 25-27, 2003

objective of these regulations is protection of humans, wildlife and the entire environment against potential risks created by application of sludge to land.

In Poland, the fundamental principles of sewage sludge utilization are outlined in the Waste Act of $27^{\text {th }}$ of June 1997. Regulation of the Environment Department from the $1^{\text {st }}$ of August 2002 [4] defines detailed instructions concerning land application of sewage sludge, including sludge quality, doses of sludge applied to soil as well as range, frequency and methods of investigations of sewage sludge and soils amended with sewage sludge.

Due to Koblak-Kalinska [5], Polish regulations ought to be consistent with the UE Directive 86/278/EEC of $12^{\text {th }}$ June 1986 concerning environmental protection, especially soils amended with sewage sludge. However Polish regulations, apart from sludge utilization in agriculture, also refer to reclamation of land for non-agricultural purpose, consolidation of soil surface, land-fills, excavations and embankments by plants as well as agrotechnical transformation of sewage sludge into compost $[4,5]$.

In the IB Annex to the UE Directive, the admissible concentrations of heavy metals in sewage sludge applied in agriculture is given (Table 1). The corresponding values required by the Polish Regulation are also presented in Table 1. According to the Polish Regulation, the concentration of heavy metals in sludge depends on the purpose it is used for. Three cases are distinguished: agriculture or reclamation of land for cultivation, reclamation of land for other purpose (not for cultivation) and transformation of soils to meet specific requirements.

Table 1. The admissible concentrations of heavy metals in sewage sludge applied to land

\begin{tabular}{|c|c|c|c|c|}
\hline \multirow[t]{2}{*}{ Element } & \multirow{2}{*}{$\begin{array}{c}\text { Directive } \\
\text { 86/278/EEC } \\
\mathrm{mg} \cdot(\mathrm{kg} \mathrm{d.m} .)^{-1}\end{array}$} & \multicolumn{3}{|c|}{$\begin{array}{l}\text { Regulation of Environment Department, } 1^{\text {st }} \text { August } 2002 \\
\text { mg.(kg d.m. })^{-1}\end{array}$} \\
\hline & & $\begin{array}{l}\text { in agriculture and } \\
\text { reclamation of land } \\
\text { for cultivation }\end{array}$ & $\begin{array}{l}\text { for reclamation of } \\
\text { land for other (not } \\
\text { cultivation) } \\
\text { purpose }\end{array}$ & $\begin{array}{l}\text { for transformation of } \\
\text { soils to meet specific } \\
\text { requirements }\end{array}$ \\
\hline lead $(\mathrm{Pb})$ & from 750 to 1200 & 500 & 1000 & 1500 \\
\hline cadmium $(\mathrm{Cd})$ & from 20 to 40 & 10 & 25 & 50 \\
\hline mercury $(\mathrm{Hg})$ & from 16 to 25 & 5 & 10 & 25 \\
\hline nickel (Ni) & from 300 to 400 & 100 & 200 & 500 \\
\hline $\operatorname{zinc}(\mathrm{Zn})$ & from 2500 to 4000 & 2500 & 3500 & 5000 \\
\hline copper $(\mathrm{Cu})$ & from 100 to 1750 & 800 & 1200 & 2000 \\
\hline chromium $(\mathrm{Cr})$ & not restricted & 500 & 1000 & 2500 \\
\hline
\end{tabular}

According to Bernacka and Pawłowska [6], the average concentration of zinc in sewage sludges in Poland was 3862 (from 215 to 8070) and the average concentration of cadmium was about 40 (from 10 to 85 ). These values remarkably exceed the admissible concentrations. In the IC Annex of the UE Directive the admissible loads of heavy metals that can be discharged to cultivated land, average in the 10-years period, are defined (Table 2). 
KALMAR ECO-TECH'03

Bioremediation and Leachate Treatment

KALMAR, SWEDEN, November 25-27, 2003

Table 2. The admissible loads of heavy metals that can be discharged to cultivated land, average in the 10-years period

\begin{tabular}{|l|c|c|}
\hline \multicolumn{1}{|c|}{ Element } & $\begin{array}{c}\text { Directive 86/278/EEC } \\
\mathrm{kg} \cdot \mathrm{ha}^{-1} \cdot \mathrm{a}^{-1}\end{array}$ & $\begin{array}{c}\text { Regulation of Environment Department from } \\
\mathrm{I}^{\text {st }} \\
\text { August 2002 } \\
\mathrm{kg} \cdot \mathrm{ha}^{-1} \cdot \mathrm{a}^{-1}\end{array}$ \\
\hline cadmium & 0.15 & 0.15 \\
\hline copper & 12 & 12 \\
\hline nickel & 3 & 3 \\
\hline lead & 15 & 15 \\
\hline zinc & 30 & 30 \\
\hline mercury & 0.10 & 0.10 \\
\hline chromium & not restricted & 15 \\
\hline
\end{tabular}

The Regulation of Polish Environment Department also refers to the sanitary quality conditions. According to this Regulation, sewage sludge applied to soil fertilization and amendment must not contain any bacteria of the Salmonella gender and the number of invading ova of enteric parasites (Ascaris sp., Trichuris sp., Toxocara $s p$.) in $1 \mathrm{~kg}$ of raw sludge must not exceed 10. The maximal admissible loads of sludge applied for soil fertilization are $10 \mathrm{t}$ of d.m. ha ${ }^{-1}$ every 3-4 years. The maximal loads in the case of reclamation of soil-less lands or amendment of soil for non-agricultural purposes are from 40 to $220 \mathrm{t}$ of d.m.ha ${ }^{-1}$ (applied only once).

The concentrations of some hazardous organic compounds, occasionally found in sludge (for instance dioxins and furans (PCDD, PDCF), PCBs, chloroorganic pesticides (DDT, aldrin, dieldrin, lindan), AOXs and PAHs) are not restricted in Poland yet [7].

Sewage sludge must not be applied to acidified soils $(\mathrm{pH}<5)$ and at the sites where groundwater table is less than $150 \mathrm{~cm}$ beneath the ground surface.

In Poland the amounts of sewage sludge discharged to the cultivated lands cannot exceed $10 \mathrm{t} \mathrm{d} . \mathrm{m} \cdot \mathrm{ha}^{-1}$ every 4 years (or $40-220 \mathrm{t}$ of d.m. $\mathrm{ha}^{-1}$ in case of land reclamation - one time application of the whole dose).

The admissible loads of sewage sludge in agricultural are as follows:

$\begin{array}{ll}\text { USA - no more than } & 5.5 \mathrm{t} \mathrm{d} \cdot \mathrm{m} \cdot \mathrm{ha}^{-1} \\ \begin{array}{ll}\text { Finland - } & 4 \mathrm{tha}^{-1} \cdot \mathrm{a}^{-1}, \\ \text { Norway - } & 2 \mathrm{tha}^{-1} \cdot \mathrm{a}^{-1}, \\ \text { Sweden - } & 1 \mathrm{t} \mathrm{ha} \mathrm{h}^{-1} \cdot \mathrm{a}^{-1}, \\ \text { The Netherlands - } & 1 \mathrm{t} \mathrm{ha} \cdot \mathrm{a}^{-1}\end{array}\end{array}$

Only the Norwegian regulations allow for $50 \mathrm{t} \mathrm{d} \cdot \mathrm{m} \cdot \mathrm{ha}^{-1}$ in a single dose. In Denmark the concentrations of cadmium are decisive for the loads of sludge - the maximal load of cadmium is $0.15 \mathrm{~kg} \mathrm{ha}^{-1} \cdot \mathrm{a}^{-1}$; if the concentration of cadmium in sludge is equal to $10 \mathrm{~kg} \cdot \mathrm{t}$ d.m. ${ }^{-1}$, then the admissible dose of sludge is $0.66 \mathrm{tha}^{-1} \cdot \mathrm{a}^{-1}[8]$. 


\section{CHARACTERISTIC OF SLUDGE FROM WWTP “WSCHOD” IN GDANSK}

\subsection{Technological line of WWTP "Wschod"}

The WWTP "Wschod" is located in the eastern part of Gdansk. At present the sewage inflow is about $90000 \mathrm{~m}^{3} \cdot \mathrm{d}^{-1}$, but the plant capacity is $180000 \mathrm{~m}^{3} \cdot \mathrm{d}^{-1}$. The effluent is discharged to the Bay of Gdansk.

Mechanical treatment consists of screens, aerated sand trap and radial primary sedimentation tanks. Biological treatment system consists of 6 multiphase MUCT reactors (modified UCT system) and 12 radial-flow secondary sedimentation tanks. The first stage of biological treatment takes place in the anaerobic chamber, where also activated sludge from denitrification chamber is recirculated. Then the sewage pass through sludge denitrification chamber and inflow to anoxic chamber, where denitrification of the nitrates brought with recirculate from nitrification chamber takes place. Before the internal recirculation stream enters anoxic chamber, it is retained in the de-aeration chamber to reduce dissolved oxygen concentration. The final stage of biological treatment system is aerobic chambers. Part of aerobic chambers volume can alternately work as denitrification or nitrification zone. In order to provide required phosphorus elimination, simultaneous precipitation of this element with iron sulphate (PIX) can be applied.

\subsection{Sewage sludge processing and quantities}

Two types of sewage sludge are generated in the WWTP:

- primary sludge, separated in primary sedimentation tanks (approximately $5.2 \%$ d.m.; $\left.440 \mathrm{~m}^{3} \cdot \mathrm{d}^{-1}\right)$,

- excess activated sludge, separated in secondary sedimentation tanks (about $0.7 \%$ d.m., $\left.460 \mathrm{~m}^{3} \cdot \mathrm{d}^{-1}\right)$.

Sludge processing line consists of:

- mechanical thickening of excess activated sludge on Klein belt presses (5.6\% d.m.),

- mixing of primary sludge and thickened excess sludge,

- mesophillious anaerobic fermentation of mixed sludge in closed chambers, in temperature range $\left(33-35^{\circ} \mathrm{C}\right)$,

- mechanical dewatering on Noxon centrifuges (average d.m. content: 15.3\%).

Part of mixed sludge is digested not in the closed chambers but in open fermentation ponds.

The annual production of sludge generated at subsequent stages of processing, in the year 2002 , is given in Table 3. 
KALMAR ECO-TECH'03

Bioremediation and Leachate Treatment

KALMAR, SWEDEN, November 25-27, 2003

Table 3. The annual sludge production in the WWTP "Wschod" in Gdansk, 2002.

\begin{tabular}{|l|c|c|c|}
\hline \multicolumn{1}{|c|}{ Type of sludge } & $\mathrm{m}^{3}$ & $\mathrm{Mg}$ d.m. & $\%$ d.m. \\
\hline primary sludge & 157000 & 8106 & 5.2 \\
\hline excess activated sludge & 1169102 & 8519 & 0.7 \\
\hline thickened excess activated sludge & 164438 & 9141 & 5.6 \\
\hline mixed sludge pumped to open fermentation ponds & 15508 & 711 & 4.6 \\
\hline $\begin{array}{l}\text { mixed sludge pumped to closed fermentation } \\
\text { chambers }\end{array}$ & 305928 & 11607 & 3.8 \\
\hline digested sludge from fermentation chambers & 291518 & 8721 & 3.0 \\
\hline mechanically dewatered on centrifuges & 52831 & 8058 & 15.3 \\
\hline
\end{tabular}

Dewatered sludge is periodically stored at the local storage site in the WWTP. Then it is transported to its final destination site.

Up till now, the whole annual production of dewatered sludge was applied to reclamation of post-industrial or soil-less lands, though finding such sites is becoming more and more difficult as most of such areas in and around Gdansk have already been amended with the sludge.

\section{RECLAMATION OF PHOSPHOGYPSUM DEPOSITION SITE IN WISLINKA NEAR GDANSK WITH SEWAGE SLUGDE FROM WWTP "WSCHOD”}

Phosphogypsum is a waste material generated during production of phosphoric acid (phosphoric fertilizer) from phosphorites and apatites. The main component of phosphogypsum is hydrated calcium sulphate, though it also contains pollutants adsorbed on its surface: acids (phosphoric acid, fluoric acid and sulphuric acid) and salts (for instance sodium fluorosilicate, sodium sulfate, sodium and calcium phosphates and other). Presence of these additives results in very low $\mathrm{pH}$ of phosphogypsum, which is usually between 1.5 and 3.5 .

Due to high water content (20-30\%) and pollution with fluorine, utilization of phosphogypsum meets a number of problems. Although intensive research on methods of safe phosphogypsum utilization has been carried out in many countries, deposition in landfills or surface waste-tips continues to be the leading way of disposal. Chemical manure plants located close to open cast mines of phosphorites and apatites usually use phosphogypsum for filling exploitation hollows. Unfortunately, mineral deposits and mines are located in Northern Africa (Marocco) and in the Kola Peninsula (Russia). Raw materials are extracted and transported by ships to other countries, where fertilizers are produced. In Poland there are three chemical fertilizer production plants, one of them in Gdansk. Until early 1990s the annual production of phosphogypsum in Poland (from three plants) amounted to about $4 \mathrm{mln}$ tonnes. This was due to the fact that during production of 1 ton of orthophosphoric acid (by means of wet method which was used at that time) approximately 5.5 tonnes of waste phosphogypsum was generated. In the 
recent years, more attention was put to environmental issues, which resulted in changes in production process leading to minimization of waste production. Another reason for lower phosphogypsum amounts was decreased demand for fertilizers from Polish farmers caused by recession.

Environmental threats imposed by phosphogypsum deposition sites result from the following features of deposited material: low $\mathrm{pH}$, high concentration of phosphates (on average from 1.0 to $3.5 \% \mathrm{P}_{2} \mathrm{O}_{5}$, but in some cases it is even 5\%), fluorine content (from 0.1 to $2 \%$ ) and presence of radionuclides [9]. Low pH of deposited waste may cause degradation of surface and ground waters, when the acids are washed away by rainwater. Presence of high phosphates amounts also endangers waters since it can cause eutrophication. Fluorine in phosphogypsum is present in the form of sodium fluorosilicate which is extremely toxic even at low concentrations. It is located mainly in silty fraction eroded by wind and moved in the form of dust deposits. Admissible levels of gamma radiation may be exceeded due to radionuclides presence.

Fertilizer production plant "Fosfory" in Gdansk has a status of dangerous production plant in Poland and phosphogypsum production and deposition is probably one of the main reasons for this. The plant produces 516000 tonnes of phosphogypsum a year. Phosphogypsum is deposited on the waste-tip located at the distance of about $30 \mathrm{~km}$ from the plant, in the village Wislinka, at clay exploitation hollow of a former brickwork, near the Martwa Vistula River - the estuary branch of the Vistula River. The site is located in the depression of Alluvial Fens of Vistula; the original elevation of land was about $1 \mathrm{~m}$ above sea level. In the early 1970 s the waste-tip was $10-15 \mathrm{~m}$ high; in late $1980 \mathrm{~s}$ it was $42 \mathrm{~m}$ high. The maximal height of phosphogypsum waste-tip can be $60 \mathrm{~m}$. At present the deposition site area is about 30 ha. Due to high water level in the tip area (13 m above sea level), wastewater infiltrates to the bottom of the tip and to surface waters near it. Wind erosion of dust was a reason of contamination of pastures here.

Pollution of streams adjacent to the tip and pollution of air with dust for many years have been a reason for protests of ecologists and local citizens, especially in the last decade, when awareness of the local communities of health and environmental risks associated with the deposition site increased. Although production of phosphogypsum in the recent years decreased (see Table 4), the waste-tip in Wislinka remains. The best solution of this problem seemed forming a layer of soil-like material on the slopes to prevent wind erosion. Sewage sludge was successfully used before for reclamation of many postindustrial and soil-less areas, for instance mine-tips of hard and brown coal mining and fly ashes from heat and power generating plants $[3,9]$.

Table 4. The amount of phosphogypsum generated in fertilizer production plant "Fosfory" in Gdansk in the years $1991-2001\left(t \cdot a^{-1}\right)$ [10].

\begin{tabular}{|l|c|}
\hline Year & $\begin{array}{c}\text { Amount of generated } \\
\text { phosphogypsum }\left(t \cdot a^{-1}\right)\end{array}$ \\
\hline 1991 & 380000 \\
\hline 1992 & 250000 \\
\hline 1993 & 108000 \\
\hline
\end{tabular}


KALMAR ECO-TECH'03

Bioremediation and Leachate Treatment

KALMAR, SWEDEN, November 25-27, 2003

\begin{tabular}{|l|l|}
\hline 1994 & 255000 \\
\hline 1995 & 244500 \\
\hline 1996 & 312800 \\
\hline 1997 & 338800 \\
\hline 1998 & 399900 \\
\hline 1999 & 237500 \\
\hline 2000 & 232000 \\
\hline 2001 & 131600 \\
\hline
\end{tabular}

Land reclamation of phosphogypsum deposition site with sewage sludge was first started in 1999. At that time the sludge was taken from WWTP "Zaspa" in Gdansk. Altogether $4200 \mathrm{t}$ d.m. of sludge was spread on the slopes. In the following years reclamation of the tip have been continued, using the sludge from WWTP "Wschod". The distance between WWTP "Wschod" and the waste-tip in Wislinka is less than $10 \mathrm{~km}$. The dewatered sludge was taken from the piles at the local storage site of the WWTP and transported by lorries to Wislinka. In the Table 5 the amounts of sludge applied on the phosphogypsum deposition site each year are listed. The sludge was taken on average once a month, apart from winter seasons.

Table 5. Sludge amounts applied to reclamation of phosphogypsum waste-tip in Wislinka.

\begin{tabular}{|l|c|c|}
\hline Year & Quantity of sludge $\left[\mathrm{m}^{3}\right]$ & Quantity of sludge [t d.m.] \\
\hline 1999 & $10500^{*}$ & $4200^{*}$ \\
\hline 2000 & 20827 & 6179 \\
\hline 2001 & 33000 & 6064 \\
\hline 2003 & 34810 & 5566 \\
\hline sum 1999-2003 & 99137 & 22009 \\
\hline
\end{tabular}

*sewage sludge from WWTP "Zaspa" in Gdansk

The quality of sludge was each time monitored by independent laboratories, for instance by Regional Sanitary and Epidemiological Control Station in Gdansk and by the Regional Inspectorate of Environmental Protection in Gdansk. Both concentrations of heavy metals and sanitary quality indicators met the obligatory criteria regarding sludge applied to land reclamation. Samples of sludge collected and examined by these institutions did not contain invading ova of enteric parasites. In some samples dead ova were found (the number fluctuated in the range from 51 to 464 dead ova of per $1 \mathrm{~kg}$ of d.m.). In Table 6 the range of heavy metals concentrations and average values in 2002 are given.

Table 6. Quality of sewage sludge generated in the WWTP "Wschod" in Gdansk, 2002.

\begin{tabular}{|l|c|c|c|c|c|}
\hline Parameter & Unit & $\begin{array}{c}\text { The } \\
\text { lowest } \\
\text { value }\end{array}$ & $\begin{array}{c}\text { The } \\
\text { highest } \\
\text { value }\end{array}$ & Average & $\begin{array}{c}\text { Max for sludge applied to } \\
\text { land reclamation } \\
\text { according to Regulation } \\
\text { of Env. Dep. of the 1 }\end{array}$ \\
st
\end{tabular}


KALMAR ECO-TECH'03

Bioremediation and Leachate Treatment

KALMAR, SWEDEN, November 25-27, 2003

\begin{tabular}{|c|c|c|c|c|c|}
\hline ammonia nitrogen & [mg N/kg d.m.] & 0.45 & 1.57 & 0.85 & - \\
\hline total phosphorus & [mg P/kg d.m.] & 8.8 & 21.6 & 15.1 & - \\
\hline calcium & {$[\mathrm{mg} \mathrm{Ca} / \mathrm{kg} \mathrm{d}$ d.m.] } & 1.1 & 5.9 & 4.4 & - \\
\hline magnesium & [mg Mg/kg d.m.] & 0.1 & 5.1 & 1.0 & - \\
\hline lead & [mg Pb/kg d.m.] & 49.7 & 121.5 & 84.1 & 1000 \\
\hline cadmium & [mg Cd/kg d.m.] & 3.5 & 13.9 & 7.4 & 25 \\
\hline chromium & [mg Cr/kg d.m.] & 47.8 & 129.9 & 83.9 & 1000 \\
\hline copper & [mg Cu/kg d.m.] & 216.3 & 454.6 & 364.3 & 1200 \\
\hline nickel & [mg Ni/kg d.m.] & 18.8 & 51.1 & 30.0 & 200 \\
\hline mercury & [mg Hg/kg d.m.] & 0.07 & 4.56 & 3.09 & 10 \\
\hline zinc & [mg Zn/kg d.m.] & 482.7 & 1954.3 & 1302.5 & 3500 \\
\hline
\end{tabular}

The sludge was transported by lorries to the bottom of the tip, discharged and then transported on the top of the tip by belt conveyor. Finally it was spread on the slopes by workers. The reason for applying dewatered sludge (with the d.m. content of about 15$17 \%$ ) is that it is obviously easier to transport and then to spread on the slopes. Unfortunately, due the soil-like consistence the dewatered sludge is less sticky than sludge with higher water content and often falls down on steep slopes of the tip. Realizing this, it is tried to adapt water content in sludge to the slopes, more moist with gentle slopes and drier for steeper slopes.

In spite of these application problems, about half of the tip slopes area is currently covered with sludge. Altogether almost $100000 \mathrm{~m}^{3}$ (over $22000 \mathrm{t} \mathrm{d.m}$.) of sludge was applied. The slopes turned black, instead of white, and succession of vegetation has started.

\section{CONCLUSIONS}

Phosphogypsum deposit in Wislinka is one of the biggest environmental and health problems in the region of Gdansk. Application of sewage sludge from the nearby municipal WWTP offers a reasonable solution to this problem. Covering of the slopes with a layer of sludge will substantially decrease wind erosion. Formation of an organic layer on the mineral deposit gives a chance to plants succession. At the same time, it is a good opportunity of utilization of at least some part of generated sludge. Sludge application should be continued until all the slopes are covered. Sludge quality should be regularly checked to avoid contamination of surface and ground waters.

\section{REFERENCES}

[1] Van der Roest H.F., Roeleveld P., Stamperius P. (1999). Optimising sludge treatment in the Netherlands. Water 21 8-9: 23-25.

[2] Wei Y., Van Houten R.T., Borger A., Eikelboom D.H., Fan Y. (2003). Minimization of excess sludge production for biological wastewater treatment. Wat. Res. 37 (2003): 4453-4467.

DOI: https://doi.org/10.1016/S0043-1354(03)00441-X 
[3] Siuta J. (1998). Conditions and methods of land application of sewage sludge. [In]: Fundamentals on sewage sludge processing and utilization. Krakow, 11-12 V 1998. Wyd. LEM, 4-1 - 4-20, Krakow.

[4] Regulation of the Ministry of Environment of the $1^{\text {st }}$ August 2002. Dz.U.02/134/1140.

[5] Koblak-Kalinska E. (1996). Legislatory aspects of sewage sludge utilization. Workshop on Practical Aspects of Municipal Sewage Sludge Utilization. Gdansk Water Foundation, Gdansk, September 1996, 2-6. [in Polish]

[6] Bernacka J., Pawłowska L. (1994). Utilization of sewage sludge from municipal WWTPs. Instytut Ochrony Srodowiska, Warszawa. [in Polish]

[7] Urbaniak M. (1997). Processing and utilization of municipal sewage sludge. Wyd. Ekoinzynieria, Lublin - Lodz, 80.ẹin Polish]

[8] Drzewiński S., Herman K., Kowalik P., Sienkiewicz E. (1999): Sewage sludge utilization for the municipality of Gdansk. In: Hogland W. (Ed.): Proceedings of Kalmar ECO-TECH'99, Kalmar 22-24 September 1999; Kalmar 1999.

DOI: https://doi.org/1 0.15626/Eco-Tech.1999.018

[9] Quant B. (1997). Silicatization of fly ash and phosphogypsum - safe for environment method of waste utilization. Zeszyty Naukowe Politechniki Gdanskiej 557, Budownictwo Wodne NreXLIV, Gdansk 1997: 115. [in Polish]

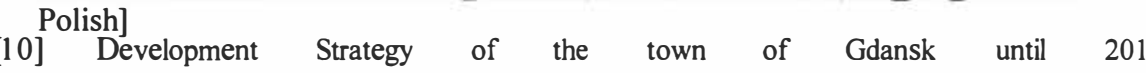
0: www.gdansk.gda.pl/umyellow/p publikacje/graphics.pdf./projekt stg 2010.pdf [in Polish]
} 